\title{
A CELERIDADE PROCESSUAL E A PADRONIZAÇÃO DAS DECISÕES COM AS SÚMULAS VINCULANTES: O DIREITO AO CONTRADITÓRIO
}

\author{
Gabriela Soares Balestero*
}

\begin{abstract}
Sumário: 1. INTRODUÇÃO 2. CRÍTICA ÀS SÚMULAS VINCULANTES 3. A NECESSIDADE DE MUDANÇA DO PAPEL DO PODER JUDICIÁRIO 4. CONSIDERAÇÕES FINAIS REFERÊNCIAS BIBLIOGRÁFICAS
\end{abstract}

\begin{abstract}
RESUMO: A finalidade deste estudo é estudar, analisar a questão do ativismo judicial, ou seja, a degeneração de um processo criado de forma solipsista pelo magistrado, sem a participação das partes para a construção do provimento. Portanto, o presente estudo possui dois objetivos específicos: 1) a reformulação processual sob uma perspectiva democrática; 2) a construção do provimento Jurisdicional pelos sujeitos do processo em simétrica paridade de armas. A edição das Súmulas Vinculantes pelo Supremo Tribunal Federal comprova o desgaste do processo jurisdicional ao trazer o comportamento ativista do Poder Judiciário atuando de forma legiferante, criando o direito de maneira antidemocrática. A análise de tal questão é o objetivo deste estudo.

Palavras - chave: Ativismo Judicial; participação das partes; reformulação processual; paridade
\end{abstract} de armas; Súmulas Vinculantes.

\begin{abstract}
The purpose of this paper is to study, analyze the issue of judicial activism, the degeneration of a process created in a solipsistic by the magistrate, without the participation of stakeholders to build the appeal court. Therefore, this study has two objectives: 1) the reformulation procedure in a democratic perspective, 2) the construction of the court dismissed the subject of the proceedings at parity symmetric arms. The issue of Súmulas Vinculantes the Supreme Court shows the wear of the judicial proceedings to bring the behavior of activist judiciary acting in a law-creating, creating the right way undemocratic. The analysis of this question is the goal of this paper.
\end{abstract}

Keywords: Judicial Activism; stakeholder; overhaul procedures; parity of arms; Binding Precedents.

\section{INTRODUÇÃO}

No presente estudo será analisado a postura do Poder Judiciário na edição das súmulas vinculantes pelo Supremo Tribunal Federal, seus aspectos positivos e negativos, bem como a importância das partes na construção do provimento jurisdicional, analisando a questão do ativismo judicial, sob o ponto de vista habermasiano.

As Súmulas Vinculantes são o retrato da tentativa do Poder Judiciário em criar o direito, legislar e congelar a interpretação, adentrando, assim, no papel do legislativo, na tentativa de propiciar uma prestação jurisdicional mais célere.

Contudo, tal celeridade trazida pela reforma do judiciário pode ocasionar consequiências graves como a insegurança jurídica e a imposição vinculante de fundamentação das decisões judiciais pelos tribunais superiores,

\footnotetext{
* Mestranda em Direito Constitucional pela Faculdade de Direito do Sul de Minas; Especialista em Direito Constitucional e em Direito Processual Civil pela FDSM; Advogada e professora.
} 
inibindo a possibilidade do magistrado e dos interessados em construir uma decisão judicial pautada na participação democrática de todos os interessados e mais adequada constitucionalmente e justa para aquele caso.

Nesse passo, será analisada a importância das partes na construção do provimento, consoante a teoria habermasiana, bem como a questão do ativismo judicial, decorrente das decisões solipsistas e muitas vezes arbitrárias do Poder Judiciário brasileiro.

Alguns questionamentos são pertinentes ao presente estudo como quais seriam os limites do julgador na tomada de decisões e poderia Judiciário atuar como substituto do legislador no tratamento de questões que não estariam previstas legalmente.

Nesse passo, pretendem-se discutir quais seriam os limites do Poder Judiciário na tomada de decisões de maneira que o provimento Jurisdicional seja construído de maneira democrática.

Um modelo democrático de processo deve seguir a perspectiva habermasiana e fazzalariana, na qual há uma estrutura policêntrica em que há a participação de todos os sujeitos envolvidos no processo na construção do provimento Jurisdicional.

A contribuição do presente estudo para o direito é trazer a perspectiva habermasiana ao processo jurisdicional de maneira a tentar alcançar um processo constitucional democrático.

Eis o objetivo do presente estudo.

\section{CRÍTICA ÀS SÚMULAS VINCULANTES}

Desde as primeiras décadas da República somos marcados pela crise do Judiciário e pelas Propostas de Reforma, e, na tentativa de solucionar os problemas como a lentidão da prestação jurisdicional, o abarrotamento do Judiciário, a suposta perda de tempo no julgamento de milhares de causas idênticas, foram criadas as Súmulas vinculantes.

A busca pela celeridade processual, pelo julgamento rápido em todas as instâncias, em especial os tribunais superiores não significa que as garantias processuais das partes, como contraditório e a ampla defesa, necessitem ser violadas.

Com as Súmulas Vinculantes a fundamentação das decisões das instâncias inferiores se tornarem restritas e pré determinadas, ou seja, a decisão do julgador passa a ter como único fundamento a súmula e não a matéria probatória e jurídica trazida pelas partes na construção de um provimento jurisdicional adequado ao caso em questão.

Nesse sentido, o Supremo Tribunal Federal passou a disciplinar o conteúdo das diversas sentenças dos juízos das instâncias inferiores do país, violando o princípio da inexistência da hierarquia entre os tribunais, da função 
legislativa, do livre convencimento do juiz e da independência funcional do magistrado enquanto agente público no exercício de suas funções. ${ }^{1}$

A Súmula Vinculante visa congelar a interpretação, pois está sendo transformada em um texto universalizante ${ }^{2}$, criando mais texto, ou seja, mais norma, na tentativa de resolver os problemas do abarrotamento do Poder Judiciário, eliminando de imediato as causas idênticas e que se enquadrem no disposto da súmula. Portanto, o caráter de orientação das súmulas se transformou em obrigatoriedade em prol da celeridade processual.

Falávamos do problema na crença do texto, que jaz em tentativas como a da Emenda. Acredita-se que os problemas do Judiciário podem ser resolvidos a partir do momento em que o STF, à maneira do common Law, estabeleça um texto que servirá de precedente vinculante para que os demais Tribunais interpretem num certo sentido a aplicação de uma lei a certa situação. ${ }^{3}$

Nessa vereda, com as Súmulas Vinculantes pretende-se que os juízes não possam julgar de maneira diferente naqueles casos disciplinados pela súmula, fazendo com que a citação da própria súmula na fundamentação seja a motivação das sentenças judiciais.

Constata-se, portanto, que, a celeridade processual, a perda de tempo no julgamento de causas consideradas pelo Supremo como idênticas, é a principal razão para a criação do instituto da Súmula Vinculante.

A criação das Súmulas Vinculantes é ainda justificada pela racionalidade instrumental pela qual passa o Poder Judiciário ${ }^{4}$, na qual os

1 "A existência de um enunciado (geral e abstrato) do STF que não apenas oriente os demais Tribunais, mas que se pretende "a única interpretação correta" para determinada norma, em certa situação e que deve obrigatoriamente ser seguida, além de criar uma hierarquia artificial entre o STF e os demais Tribunais, desnuda algumas idéias que parte da doutrina e jurisprudência brasileiras conservam." (BAHIA, Alexandre Gustavo Melo Franco. Recursos Extraordinários no STF e no STJ: conflito entre interesses público e privado. Curitiba: Juruá Editora, 2009, p. 204.)

${ }^{2}$ Expressão usada por STRECK, Lênio Luiz. Jornal Carta Forense: entrevista Direito Sumular. Disponível

em: http://leniostreck.com.br/index.php?option=com_content\&task=view\&id=82\&Itemid=2. Acesso em: 29 jan.2009.

${ }^{3}$ BAHIA, Alexandre Gustavo Melo Franco. Recursos Extraordinários no STF e no STJ: conflito entre interesses público e privado. Curitiba: Juruá Editora, 2009, p. 213/214.

4 "Em parecer que exarei, sustentei que as súmulas, enquanto verbetes jurisprudenciais com caráter de abstração e generalidade, não podem ser aplicados sem observância à faticidade tanto do(s) caso(s) concreto(s) precedente(s), quanto do caso concreto sobre o qual se pretende a 'incidência'. Precedentes não são significantes primordiais - fundantes (de cariz aristolélico - tomista), nos quais estariam contidas aas universalidades de cada caso jurídico, a partir das quais o intérprete teria a simplista tarefa de "subsumir" o particular ao geral/universal. E o caso concreto, efetivamente, trazia um suporte fático distinto, que não enseja a 'aplicação' da referida súmula: o acusado se encontrava preso desde outubro de 2006. E não me parece que, quando se fez a Súmula 21, tenha-se pensado em prazos tão dilatados e decorridos nas circunstâncias específicas do presente caso. Não seria, afinal, exigível do Estado/Juiz uma maior celeridade no tratamento de caso que, por sua gravidade, exige a segregação processual do réu? Daí a necessidade da reconstrução histórico - institucional do direito. Com efeito, a 
processos são analisados apenas com a idéia de custo beneficio e não como meio para efetivamente assegurar o direito das partes.

Ingenuamente, em busca de uma única interpretação correta o Supremo Tribunal Federal acredita que através da inclusão de mais textos ${ }^{5}$, por intermédio agora das Súmulas Vinculantes ocasionaria a capacidade de solucionar a insegurança jurídica ocasionada pela diversificação da atividade interpretativa e pela complexidade social.

Portanto, alguns questionamentos a respeito do instituto das Súmulas Vinculantes devem ser analisados como: poderia uma súmula com caráter apenas de orientação vincular os demais juízes e tribunais do país além de vincular a própria fundamentação das decisões judiciais? A Súmula Vinculante sendo um texto está sujeita apenas a uma interpretação? A diversidade da interpretação de uma Súmula Vinculante pode gerar a diversidade de sua aplicação? A Súmula Vinculante teria mais força normativa que uma lei aprovada pelo legislativo? Existem casos idênticos? Será que um juiz ao exercer o controle difuso de constitucionalidade não pode não pode declarar uma Súmula Vinculante Inconstitucional?

Os nossos tribunais sempre tiveram a tendência de que as instâncias inferiores seguissem a orientação jurisprudencial das instâncias superiores. Contudo, devido ao princípio da inexistência de hierarquia entre os tribunais, tal situação era facultativa e hoje, com as Súmulas Vinculantes o que era opcional passou a ter caráter obrigatório.

Súmula 21 - instituída em 1990 - deve ser reexaminada e, conseqüentemente, redefinida. Explico: a súmula é anterior à Emenda Constitucional n. 45, que estabeleceu como direito fundamental a duração razoável do processo. Há, pois, um direito fundamental a prazo razoável, mormente quando o processado se encontra segregado - em qualquer das modalidades de prisões processuais - durante a apuração de sua responsabilidade criminal. Impõe-se, pois a redefinição. Todavia, não apenas em relação ao já aludido ditame constitucional, mas também deve ser reexaminada a súmula sob a perspectiva do devido processo legal e do Estado Democrático de Direito, que impede a intromissão indevida do Estado na esfera de liberdade sem um motivo razoável. Entre outras coisas, é preciso saber: o Estado comprovou que necessitava do indivíduo segregado cautelarmente todo esse período? Mais: 02 (dois) anos e 06 (seis) meses com o indivíduo à disposição do Estado não são suficientes para a apuração de sua responsabilidade penal? Mais: se o Estado, em um processo comum, consoante aponta a tradição, tem em regra 81 dias (prazo que pode, eventualmente, ser relativizado - veja-se, por exemplo, o teor da Súmula 52 do Superior Tribunal de Justiça), por que motivo no processo que se instrumentaliza pelo procedimento do Júri o prazo poderia ser aumentado em mais de 10(dez) vezes, como ocorre no caso dos autos? Com isso, não se retira a validade e a importância da(s) Súmula(s). Ocorre que, em certas circunstâncias, pode representar um instrumentalista autoritário (ou até mesmo um instrumento de acomodação) do Estado. Isto porque ao se entender (e ao se aplicar) a Súmula 21 do STJ em sua literalidade, ter-se-ia que após a pronúncia não há limites à prisão. $\mathrm{E}$ isso, ao menos nesta quadra da história, é inconcebível." (STRECK, Lênio Luiz. Verdade e Consenso. Constituição, Hermenêutica e Teorias Discursivas da Possibilidade à necessidade de respostas corretas em Direito. 3.ed. Rio de Janeiro: Lúmen Juris , 2009, p. 509/510.)

${ }^{5}$ Segundo Lênio Luiz Streck "Ao fim e ao cabo, na teoria da argumentação tudo acaba em subsunção". (STRECK, Lênio Luiz. O que é isto - decido conforme a minha consciência?. Porto Alegre: Livraria do Advogado, 2010, p. 50.) 
O caráter vinculante da súmula induz e obriga a conduta individual do magistrado ${ }^{6}$, porque é produto de um órgão coletivo que é o tribunal. Ela pretende uma única interpretação correta de maneira a criar uma hierarquia entre o STF e os demais Tribunais.

A regra não é clara ${ }^{7}$ e, portanto, está sujeita a diversas interpretações, ou seja, consoante o postulado de Kelsen, não há um sentido verdadeiro na norma já que todas estão sujeitas a várias interpretações através do trabalho realizado pela doutrina e pela jurisprudência. Portanto, as súmulas vinculantes, sendo também normas, estariam sujeitas a várias interpretações.

Segundo o entendimento de Maria Fernanda Salcedo Repolês ${ }^{8}$ "justamente porque o STF tem a última palavra sobre o que é a Constituição, ele não pode agir como se tivesse a última palavra sobre o que é a Constituição". Esse é o medo e o perigo das Súmulas Vinculantes.

Segundo Humberto Theodoro Júnior " "implantou-se a mentalidade de que reformando as leis, o Estado melhoraria no exercício do governo da

6 "Em outras palavras, segundo Sadek, o problema da crise da justiça estaria no fato de que os juízes (lato senso) não estariam preparados para a gestão administrativa - econômica do judiciário. E que, se os juízes forem melhor preparados - inclusive ou mormente em relação a saber gestionar - o Judiciário pode(ria) superar a crise. Nota-se, ademais, como os diagnósticos (e as soluções) apresentados por Sadek não enfrentam o problema dos julgamentos democráticos (por exemplo, a qualidade das decisões) e dos obstáculos à democracia representados exatamente pelos mecanismos por ela "elogiados": a súmula e a repercussão geral, para falar apenas destes, tidos como "instrumentos com capacidade de alatera o status quo na estrutura do Poder Judiciário, no tempo e na qualidade da prestação jurisdicional'. Aqui Sadek esquece, por exemplo, que as súmulas são produto da própria fragmentação das decisões, problemática nem de longe enfrentada na pesquisa. Ou seja, ignora que as súmulas sejam decorrentes de um problema paradigmático." (STRECK, Lênio Luiz. O que é isto - decido conforme a minha consciência?. Porto Alegre: Livraria do Advogado, 2010, p. 42).

7 "Há na deturpação dessa técnica uma tendência do parlamento de despojar-se, em boa parte, de sua competência legislativa, relegando ao Judiciário completar a tarefa normativa, sem que os indivíduos possam prever, com segurança jurídica, como o órgão aplicador da regra vaga irá colmatá-la. É necessário, logicamente, coibir esse tipo de abuso legislativo, para evitar que, de fato, o juiz se torne legislador; e, o que é pior, legislador ex post facto, pois a lei só será ditada em seu conteúdo completo e definitivo depois de consumado o fato sobre que irá incidir. A segurança jurídica, por sua vez, não pode conviver com problemas desse porte. É fundamental, para ter-se uma ordem jurídica como consagradora do princípio de segurança jurídica, que primeiro se observe a separação de poderes entre legislador e juiz e depois que a norma criada pelo primeiro somente seja aplicada pelo segundo aos fatos supervenientes à sua edição. É o que proclama a Suprema Corte Norte-Americana, quando insiste na necessidade de interditar "as ex post facto laws, para, assim, permitir [sempre] aos indivíduos terem um conhecimento prévio e estável das leis às quais devem se submeter e das penas às quais se expõem". (JÚNIOR, Humberto Theodoro Jr. A onda reformista do Direito Positivo e seus implicações com o princípio da segurança jurídica. Revista de Doutrina da $4^{\mathrm{a}}$ Região, Porto Alegre, n.14, set 2006. Disponível em: www.revistadoutrina.trf4.gov.br. Acesso em: 01 jun. 2010.)

${ }^{8}$ REPOLÊS, Maria Fernanda Salcedo. O papel político do Supremo Tribunal Federal e a hermenêutica constitucional: considerações partir da teoria, da cultura institucional e da Jurisprudência. Revista do Curso de Direito da Faculdade Metodista Isabela Hendrix, Nova Lima, v. 1, p. $102-108,1^{\circ}$ semestre 2003 a.p. 107.

9 JÚNIOR, Humberto Theodoro Jr. A onda reformista do Direito Positivo e suas implicações com o princípio da segurança jurídica. Revista de Doutrina da $4^{\text {a }}$ Região, Porto Alegre, n.14, set 2006. Disponível em: www.revistadoutrina.trf4.gov.br. Acesso em: 01 jun. 2010. 
sociedade e esta aprimoraria seus critérios e valores de comportamento intersubjetivo." E, baseado nesse pensamento, o Judiciário atribui para si a função de legislador, ampliando a atribuição conferida pela Constituição Federal, criando súmulas vinculantes, dotadas de força normativa na tentativa de proporcionar celeridade da máquina judiciária, limitando a fundamentação das decisões, e inibindo que todos os envolvidos no processo, incluindo o julgador, decida de maneira mais adequada para aquele caso.

Portanto, com a Súmula Vinculante ${ }^{10}$ busca-se congelar a interpretação com o fim de proporcionar maior segurança jurídica e menor litigiosidade.

Há aqueles que defendem a Súmula Vinculante no sentido de que ela seria o fruto da evolução da jurisprudência e que, portanto, não interferiria, não acarretaria desequilíbrio na esfera legislativa e proporcionaria segurança jurídica.

Nesse passo, a Súmula Vinculante traria duas pretensões que são a imutabilidade no sentido de trazer segurança jurídica e a verticalização, ou seja, a obrigatoriedade de sua aplicação nas instâncias inferiores.

Há um pensamento comum no Supremo Tribunal Federal de que há julgamentos de casos idênticos. Cabe destacar que nenhuma causa é idêntica à outra $^{11}$, haja vista que cada caso é portador de sua peculiaridade, de causa de pedir e de pedido diversos.

10 "Atrás de uma súmula - assim como em qualquer regra jurídica - há vários princípios. E da própria súmula se extrairá princípios. Pensar que a súmula é o "conceito final" da cadeia discursiva é o mesmo que pensar que a invocação da grafia de um princípio esgotará por si só a discussão. Qual é a diferença - e faço a pergunta para argumentar no mesmo nível da distinção estrutural 'regra princípio' - entre uma súmula e um princípio, se aquela tiver a característica deste? Ora, várias súmulas têm plenamente a feição daquilo que tem sido entendido como princípio (até mesmo) constitucional. E parece que não teríamos interpretações isomóficas se 'colocássemos' todos os princípios na dicção de súmulas...! Exemplo interessante exsurge das súmulas 'tautológicas' isto é, aquelas que dizem o que a lei ou a Constituição já explicitam graficamente, como é o caso da Súmula vinculante $n$. 10, que repete o art. 97 da CF; e o que dizer da súmula que diz que não cabe mandado de segurança contra lei em tese (além de repetir a lei, não esgota - e nem poderia - as diferentes hipóteses de aplicação do que seja 'lei em tese')?" (STRECK, Lênio Luiz. Verdade e Consenso. Constituição, Hermenêutica e Teorias Discursivas da Possibilidade à necessidade de respostas corretas em Direito. 3.ed. Rio de Janeiro: Lúmen Juris , 2009, p. 507.)

11 "Conseqüentemente, cada decisão jurisprudencial que siga ou inaugure uma nova cadeia discursiva - contém um núcleo mínimo generalizante, de onde se extrai um ou mais princípios, que exatamente constituem o elo com a cadeia significativa. De vários modos se dá esse processo (ou deveria se dar). Assim como não basta a citação do ementário (como também não basta a citação da lei), não é suficiente a contextualização do caso, o que pode acarretar um seguimento acrítico da cadeia aplicativa. Um 'precedente jurisprudencial' deve ser perquirido relativamente ao princípio que o institui. A súmula vinculante n. 11 que trata do uso de algemas tem seu elemento generalizante sustentado na preservação dos direitos fundamentais do preso. A complementariedade/ co - originariedade entre a aplicação do direito e a integridade exige essa reconstrução histórico - institucional (trata - se daquilo que venho denominando de DNA do caso jurídico)." (STRECK, Lênio Luiz. Verdade e Consenso. Constituição, Hermenêutica e Teorias Discursivas da Possibilidade à necessidade de respostas corretas em Direito. 3.ed. Rio de Janeiro: Lúmen Juris , 2009, p. 507/508). 
Portanto, com a criação dos institutos da Repercussão Geral e das Súmulas Vinculantes ${ }^{12}$ há uma tentativa do Supremo Tribunal Federal de simplificar os problemas tentando aumentar a segurança jurídica ${ }^{13}$, a "certeza" da aplicação do Direito.

As situações do caso concreto não são e nunca serão idênticas e muito menos abstratas, pois, sendo as Súmulas Vinculantes um texto também devem ser interpretadas quando da sua aplicação, a semelhança das leis propriamente ditas.

Cada caso concreto possui as suas peculiaridades devendo resultar em uma decisão única e adequada para aquele caso.

Nesse passo, não caberia ao Supremo Tribunal Federal sob o argumento da estabilidade jurídica, estabelecer o cânone oficial da interpretação normativa, criando barreiras de acesso aos Tribunais, pois tal pretensão não é compatível com o postulado da democracia previsto em nosso ordenamento.

Nesse sentido, o Supremo Tribunal Federal não tem o poder de criar o direito e nem de estabelecer um modelo de interpretação para aquele caso concreto, pois não é possível fechar ${ }^{14}$ a interpretação através de uma Súmula Vinculante, esquecendo os pressupostos constitucionais e processuais democráticos consagrados em nossa Constituição Federal ${ }^{15}$.

12 "Perceba-se que, como cada caso é único, a Súmula, por mais 'perfeita' que seja sua redação, será 'geral e abstrata'. 'Essas decisões são normas. Mas essas normas são transformadas em textos no momento em que assumem eficácia contra todos e efeito vinculante em relação aos demais órgãos do Poder Judiciário e da Administração direta e indireta.” (BAHIA, Alexandre Gustavo Melo Franco. Recursos Extraordinários no STF e no STJ: conflito entre interesses público e privado. Curitiba: Juruá Editora, 2009, p. 219.)

13 "A segurança que podemos ter hoje, no que se refere à aplicação de normas num Estado Democrático de Direito, não pode significar erigirmos o STF (e/ou os demais Tribunais Superiores) à condição de Censor da sociedade, de forma que a ele caiba definir o cânon oficial de interpretação normativa, buscando-se com isso gerar estabilidade ao se criarem barreiras de acesso aos Tribunais. Dessa forma, entendemos que segurança jurídica apenas pode significar hoje a garantia de que a proteção contra qualquer (alegação de) "lesão ou ameaça a direito" encontre no Judiciário a resposta adequada, ou seja, onde as partes possam ter a certeza de que a decisão foi formada a partir daquilo que elas produziram em contraditório no processo, ao mesmo tempo em que resulta da reconstrução do Ordenamento." (Ibidem, p. 220/221.)

14 "Isso talvez possa parecer um pouco estranho, dado nosso apego ao texto, não causa espécie aos juízes do common law. Já que tantos dos que defendem a Súmula Vinculante se espelham na Suprema Corte dos Estados Unidos, vale a pena lembrar que os juízes americanos, em boa parte dos casos que têm a julgar, se esforçam para se desvencilhar da força do stare decisis." (BAHIA, Alexandre Gustavo Melo Franco. Recursos Extraordinários no STF e no STJ: conflito entre interesses público e privado. Curitiba: Juruá Editora, 2009, p. 221.)

15 "É como se a Constituição permitisse que ela mesma fosse "complementada" por qualquer aplicador, à revelia do processo legislativo regulamentar (portanto, à revelia do princípio democrático). Isso seria uma "autorização" para ativismos, que, ao fim e ao cabo, deságuam em decisionismos. Ou seja, qualquer tribunal ou a própria doutrina poderiam "construir" princípios que substituíssem ou derrogassem até mesmo dispositivos constitucionais, o que, convenhamos, é um passo atrás em relação ao grau de autonomia que o Direito deve ter no Estado Democrático de Direito." (STRECK, Lênio Luiz. O que é isto - decido conforme a minha consciência?. Porto Alegre: Livraria do Advogado, 2010, p. 45.) 
Nessa vereda, ao invés do magistrado julgar de acordo com a contribuição trazida pelas partes, por todos os envolvidos no processo, construindo uma decisão mais adequada do ponto de vista constitucional para aquele caso concreto, o julgador se assujeita à coisa ${ }^{16}$, ou seja, se subordina à força normativa da súmula vinculante, não tendo a audácia de adaptá-la, ou até mesmo reformar o seu entendimento baseado na contribuição das partes no caso concreto.

Nesse passo, as várias tentativas dos Tribunais Superiores em controlar a crise do Poder Judiciário, porém com apego ao texto na tentativa de trazer celeridade processual e segurança jurídica na aplicação do direito, são contrárias a um procedimentalismo democrático.

Portanto, considerando a complexidade e os riscos da sociedade moderna é necessário a compreensão do direito como um ordenamento de princípios em que a atividade jurisdicional se move respeitando um procedimentalismo democrático discursivo (Gunther e Habermas) em que o juiz deve fundamentar e justificar as suas decisões no caso concreto considerando a sua unicidade e a partir das pretensões levantadas e debatidas pelas partes no curso processual.

\section{A NECESSIDADE DE MUDANÇA DO PAPEL DO PODER JUDICIÁRIO}

As teorias de Bülow do processo como relação jurídica entre as partes subordinadas ao juiz reduziram o processo a um instrumento para que $o$ magistrado atue de maneira solipsista ${ }^{17}$ na tomada de decisões no caso concreto.

É nessa linha que, v.g., José Roberto dos Santos Bedaque, importante e prestigiado processualista, procura resolver o problema da efetividade do processo a partir de uma espécie de "delegação" em favor do julgador, com poderes para reduzir as formalidades que impedem a realização do direito material em conflito. E isso é feito a partir de um novo princípio processual decorrente do "princípio da instrumentalidade das formas" denominado princípio da adequação ou adaptação do procedimento à correta aplicação da técnica processual. Por este "princípio" se reconhece "ao julgador a capacidade para,

${ }^{16}$ STRECK, Lênio Luiz. O que é isto - decido conforme a minha consciência?. Porto Alegre: Livraria do Advogado, 2010, p. 46.

17 "No mesmo sentido, Cândido Rangel Dinamarco - o que inaugurou com sua tese de Cátedra a corrente chamada Instrumentalidade do Processo, que influenciou e continua influenciando gerações de juristas - afirma, sem ressalvas, que o juiz é o canal privilegiado de captação dos valores sociais, devendo estes aparecerem assimilados na sentença. Nas palavras do autor: "o juiz é o legítimo canal através de que o universo axiológico da sociedade impõe as suas pressões destinadas a definir e precisar o sentido dos textos, a suprir-lhes eventuais lacunas e a determinar a evolução do conteúdo substancial das normas constitucionais". (STRECK, Lênio Luiz. O que é isto - decido conforme a minha consciência?. Porto Alegre: Livraria do Advogado, 2010, p. 39). 
com sensibilidade e bom senso, adequar o mecanismo às especificidades da situação, que não é sempre a mesma”. Mais ainda, deve "ser reconhecido ao juiz o poder de adotar soluções não previstas pelo legislador, adaptando o processo ás necessidades verificadas na situação concreta.” Em sua - refirase - sofisticada tese, embora demonstre preocupação em afastá-la da discricionariedade. Bedaque termina por sufragar as teses kartianas e kelsenianas, quando admite que as fórmulas legislativas abertas favorecem essa atuação judicial. ${ }^{18}$

O processo passa a ser o local em que o juiz atua de acordo com as suas próprias convicções e ideologias, havendo uma degeneração de todo o conteúdo da relação jurídica processual, ocasionando o descrédito do Judiciário e o protagonismo do juiz.

Tal fenômeno apelidado de ativismo judicial é sintetizado pela afirmação de Streck: "Forma-se, desse modo, um círculo vicioso: primeiro, admite-se discricionarismos e arbitrariedades em nome da 'ideologia do caso concreto', circunstância que, pela multiplicidade de respostas, acarreta um sistema desgovernado, fragmentado..."19.

A deficiência estatal na realização de políticas públicas e do legislativo na elaboração de leis que realmente acompanhem a mobilidade social e tecnológica, proporcionou a derrocada dos ideais dos Estados sociais e a busca incessante pelo Poder Judiciário na esperança da implementação das atividades essenciais da sociedade. Portanto, verifica-se, por exemplo, a judicialização da política ${ }^{20}$, da saúde, dos institutos da repercussão geral e das súmulas vinculantes, objeto do presente estudo.

Consoante Daniel Sarmento "no cenário brasileiro, o neoconstitucionalismo é também impulsionado por outro fenômeno: a descrença geral da população em relação à política majoritária e, em especial, o descrédito do Poder Legislativo e dos partidos políticos."22

${ }^{18}$ Ibidem, p. 38.

19 STRECK, Lenio Luiz. Constituição, Sistemas Sociais e Hermenêtica; Desconstruindo os modelos de juiz: a hermenêutica jurídica e a superação do sujeito - objeto”. Porto Alegre: Livraria do Advogado, 2.008, p110/111.

20 “Tal expressão ganhou delineamento a partir do trabalho coordenado por C. Neal Tate e Torjön Vallinder, intitulado The global expansion of judicial Power, no qual foi denominada de judicialização a tendência de transferir poder decisório do Poder Executivo e do Poder Legislativo para o Poder Judiciário. “ (NUNES, Dierle José Coelho. Processo Jurisdicional Democrático. Curitiba: Juruá Editora, 2008, p.179.)

${ }^{21}$ SARMENTO, Daniel. O Neoconstitucionalismo no Brasil: riscos e possibilidades. São Paulo: Revista dos Tribunais, 2009, p. 32.

${ }^{22}$ Nesse ponto, cabe informar os fatores de desestabilização democrática trazidos por Rodolfo Viana em sua obra "Direito Constitucional Democrático".Atualmente, verifica-se que diversos fatores desestabilizaram a democracia, destruindo a sua imagem romântica, perfeita, constatando-se que tal situação não ocorre apenas nos chamados países subdesenvolvidos, mas sim nos chamados países de primeiro mundo. Os fatores de desestabilização democrática são considerados causas exógenas, compreendem os fenômenos da "globalização", "complexidade" e "risco". Já as causas endógenas compreendem a "crise do princípio representativo" e a "fenomenologia do refluxo".a) Globalização: 
Isso gera uma expectativa da sociedade que o Poder Judiciário traga uma resposta para todos os problemas nacionais, como, por exemplo, os casos em que a justiça toma certas decisões baseadas na opinião pública como "mensalão", "perda de mandato por infidelidade partidária"; "nepotismo" e outros.

O Poder Judiciário figura a concepção neoliberal de produtividade, em especial, após a Emenda Constitucional n 45, trouxe à Constituição Federal brasileira a previsão expressa do princípio da celeridade processual.

Nesse passo, a produtividade judicial passa a predominar os julgamentos em massa, as ações repetitivas, as súmulas vinculantes, são o retrato de um Poder Judiciário pautado em números de julgamentos do que em análises criteriosas do caso concreto.

Surge então o ativismo judicial ocasionado pelo protagonismo do juiz, pois é entregue a ele uma capacidade sobre-humana de proferir uma decisão mais justa de acordo com as suas concepções pessoais e ideologias, em sua maioria, desprezando possíveis contribuições das partes, dos advogados e até mesmo da Jurisprudência e da doutrina.

Segundo Daniel Sarmento "muitas vezes o Poder Judiciário pode atuar bloqueando mudanças importantes promovidas pelos outros poderes em

A globalização ainda é um fenômeno e implica um novo regime, é um sistema social, econômico, político, é um fenômeno de certa universalização, pois desloca muitas decisões para fora do país, ou seja, há espaços extra nacionais, há agências, organizações, que tomam decisões. Nesse sentido, há uma interpenetração entre os níveis local e global, pois as tendências da sociedade mundial convivem com as identidades locais. Isso ocorre porque a política interna passa a ser influenciada por fatores externos, restringindo a autonomia e a liberdade da vontade popular; b) Complexidade: A complexidade é a dificuldade de adaptação da democracia em uma sociedade complexa. Para Niklas Luhmann, a "complexidade" é uma derivação conceitual relacionada essencialmente com o que se poderia chamar de "especialização funcional autorreferenciada" dos sistemas sociais. Verifica-se, pois, a dificuldade em se regulamentar uma sociedade complexa no sistema constitucional e o caráter operacional da democracia fica abalado, tendo em vista, que o indivíduo, sendo obrigado a se especializar, não tem disponibilidade para a vida pública, acabando por enfraquecer esses laços sociais de forma brusca; c) Risco: Segundo Ulrich Beck, sociedade de risco "designa um tipo de sociedade que se tornou consciente do paradoxo do conhecimento científico, ou seja, de que a produção de novos conhecimentos gera também novas incertezas".Logo, atualmente, a ciência não tem a competência de avaliar a conseqüência da meteórica evolução tecnológica, não tendo como calcular, prever e gerir os riscos do seu próprio desenvolvimento, tornando pública a sua incerteza. Há o confronto entre a democracia e a tecnocracia, havendo dúvidas quanto à competência, à capacidade do povo em suas decisões. Portanto, a democracia é desafiada a resolver temas que fogem da cognição da própria ciência. Desta forma, a tecnocracia pode acarretar o esvaziamento da política que é o cerne da democracia, e conseqüentemente as decisões sobre a implantação de tecnologias devam ser retiradas do público, reforçando a idéia da competência do povo para a definição da melhor estratégia de decisão e de governabilidade. Entretanto, tal situação também gera conflitos, pois a credibilidade do discurso tecnocrático é abalada diante do fato do homem comum não possuir capacidade técnica suficiente para fornecer respostas seguras aos problemas decorrentes das falhas da ciência; d) Refluxo: Segundo Rodolfo Viana Pereira, "o último fator de crise é representado pelo que Noberto Bobbio chamou de 'refluxo à democracia'. A expressão designa uma categoria de eventos que inclui três fenômenos particulares: $o$ afastamento da política, a renúncia à política e a recusa da política". (PEREIRA, Rodolfo Viana. Direito Constitucional Democrático. Rio de Janeiro: Lúmen Júris, 2008, p. 137). 
favor dos excluídos, defendendo o status quo. E esta defesa pode ocorrer inclusive através do uso da retórica dos direitos fundamentais." ${ }^{, 3}$

\begin{abstract}
A degeneração de um processo governado e dirigido solitariamente pelo juiz, como já criticada em trabalho anterior (NUNES, 2006, p. 23), gerará claros déficits de legitimidade, que impedirão uma real democratização do processo, que pressupõe uma interdependência entre os sujeitos processuais, uma co-responsabilidade entre estes e, especialmente, um policentrismo processual. ${ }^{24}$
\end{abstract}

Nessa vereda, busca-se um afastamento do decisionismo do julgador para que sejam abertos espaços alternativos que proporcionem a discussão, a participação dos interessados na formação das decisões.

Uma das conseqüências da inclusão da efetiva participação da população na esfera pública é o alargamento do foro tradicional da política, ou seja, os debates e as tomadas de decisões fugiriam dos foros tradicionais para alcançar outros âmbitos mais populares, como fóruns, debates via internet, associações criadas com essa finalidade, etc, de forma a utilizar os meios de comunicação como instrumento para essa abertura política à população.

$\mathrm{O}$ alargamento desses espaços alternativos para debates bem como o incentivo das informações fornecidas pelos meios de comunicação em massa podem aumentar o nível de legitimidade, de participação popular.

Como afirma Paulo Bonavides ${ }^{25}$ : "Sem participação não há sociedade democrática. A participação é o lado dinâmico da democracia, a vontade atuante que, difusa ou organizada, conduz no pluralismo o processo político à nacionalização, produz o consenso e permite concretizar, com legitimidade, uma política de superação e pacificação de conflitos."

Ademais, "o processo não pode ser, nesse contexto, enxergado como um mal a ser resolvido, eis que este constitui uma garantia de legitimidade e participação dos cidadãos na formação das decisões."26

Um processo construído a partir da comparticipação das partes permite que todos os sujeitos processuais discutam argumentos normativos para

23 'É verdade que o ativismo judicial pode, em certos contextos, atuar em sinergia com a mobilização social na esfera pública. Isso ocorreu, por exemplo, no movimento dos direitos civis nos Estados Unidos dos anos 50 e 60, que foi aquecido pelas respostas positivas obtidas na Suprema Corte, no período da Corte de Warren. Mas nem sempre é assim. A ênfase judicialista pode afastar do cenário de disputa por direitos as pessoas e movimentos que não pertençam nem tenham proximidade com as corporações jurídicas". (SARMENTO, Daniel. $O$ Neoconstitucionalismo no Brasil: riscos e possibilidades. São Paulo: Revista dos Tribunais, 2009, p. 36/37.)

${ }^{24}$ NUNES, Dierle José Coelho. Processo Jurisdicional Democrático. Curitiba: Juruá Editora, 2008, p 195.

${ }^{25}$ BONAVIDES, Paulo. Do Estado Liberal do Estado Social, Rio de Janeiro, Forense, 1980, p. 23.

${ }^{26}$ NUNES, Dierle José Coelho. Teoria do processo contemporâneo. Revista da Faculdade de Direito do Sul de Minas, Edição Especial, 2008, p. 14. 
a produção do provimento na busca de uma solução mais adequada ao caso concreto, evitando a decisões arbitrárias do julgador.

Entretanto, cabe observar que há aqueles que defendem a Súmula Vinculante no sentido de que ela seria o fruto da evolução da jurisprudência e que, portanto, não interferiria, não acarretaria desequilíbrio na esfera legislativa e proporcionaria segurança jurídica.

\begin{abstract}
Os que inquestionavelmente defendem a Súmula Vinculante esquecem-se que todo consenso é apenas o primeiro passo para um dissenso futuro - dissenso este com o qual os juízes de hoje têm de aprender a lidar. A ênfase na uniformidade vai a ponto de se afirmar, inclusive, que nem a própria Súmula pode ser interpretada, pois que isso seria a negação do próprio sentido de existir de uma Súmula, como dizia Victor N. Leal, ainda mais agora, sendo ela vinculante. ${ }^{27}$
\end{abstract}

Nesse passo, a Súmula Vinculante traria duas pretensões que são a imutabilidade no sentido de trazer segurança jurídica e a verticalização, ou seja, a obrigatoriedade de sua aplicação nas instâncias inferiores.

Há um pensamento comum no Supremo Tribunal Federal de que há julgamentos de casos idênticos. Cabe destacar que nenhuma causa é idêntica à outra, haja vista que cada caso é portador de sua peculiaridade, de causa de pedir e de pedido diversos.

Cada caso (não, necessariamente, cada processo) é único e irrepetível; logo, não há respostas tão perfeitas e definitivas que possam, resolvendo um caso, determinar a solução de todos os outros (atuais ou futuros), a interpretação é (sempre) construtiva: ao mesmo tempo em que fornece uma resposta para um caso, isso apenas é possível dada a complexidade do evento posto à decisão, que o torna único; se ele é único, a respectiva decisão não pode ser a criação de um standard que determine, a priori a solução de qualquer outro caso, ainda que "semelhante" - ainda que, justamente porque pretende ser a solução correta para o caso possa, de alguma forma, ao servir à construção do Direito, auxiliar na solução de casos futuros. ${ }^{28}$

Portanto, com a criação dos institutos da Repercussão Geral e das Súmulas Vinculantes ${ }^{29}$ há uma tentativa do Supremo Tribunal Federal de

${ }^{27}$ BAHIA, Alexandre Gustavo Melo Franco. Recursos Extraordinários no STF e no STJ: conflito entre interesses público e privado. Curitiba: Juruá Editora, 2009, p. 217.

${ }^{28}$ BAHIA, Alexandre Gustavo Melo Franco. Recursos Extraordinários no STF e no STJ: conflito entre interesses público e privado. Curitiba: Juruá Editora, 2009, p. 218.

29 'Perceba-se que, como cada caso é único, a Súmula, por mais 'perfeita' que seja sua redação, será 'geral e abstrata'. 'Essas decisões são normas. Mas essas normas são transformadas em textos no momento em que assumem eficácia contra todos e efeito vinculante em relação aos demais órgãos do Poder Judiciário e da Administração direta e indireta." (Ibidem, p. 219.) 
simplificar os problemas tentando aumentar a segurança jurídica ${ }^{30}$, a "certeza" da aplicação do Direito.

As situações do caso concreto não são e nunca serão idênticas e muito menos abstratas, pois, sendo as Súmulas Vinculantes um texto também devem ser interpretadas quando da sua aplicação, a semelhança das leis propriamente ditas.

Nesse sentido, o Supremo Tribunal Federal não tem o poder de criar o direito e nem de estabelecer um modelo de interpretação para aquele caso concreto, pois não é possível fechar ${ }^{31}$ a interpretação através de uma Súmula Vinculante, esquecendo os pressupostos constitucionais e processuais democráticos consagrados em nossa Constituição Federal.

No que tange à reforma (em sentido amplo), podemos afirmar,
com Wolfgang Hoffmann - Riem que qualquer reforma do
Judiciário somente será bem sucedida "caso seja desenvolvida e
concretizada em colaboração com eles" (tradução livre) - os
sujeitos afetados por ela, institucionais ou não. Acrescentamos
que não só deve contar com a participação deles, mas que
também se deveria pensar num outro modelo que não o que
parece guiar nossos reformadores, isto é, tudo é feito para
centralizar o sistema, fortalecendo os órgãos superiores, na
contramão da inclusão; e mais, que as reformas têm de ser
encaradas como uma atividade complexa, sujeita a decepções,
enfim, um processo de aprendizagem com possíveis
contratempos.

Nesse passo, as várias tentativas dos Tribunais Superiores em controlar a crise do Poder Judiciário, porém com apego ao texto na tentativa de trazer celeridade processual e segurança jurídica na aplicação do direito é inóqua e contrária aos pressupostos do Estado Democrático de Direito.

30 “A segurança que podemos ter hoje, no que se refere à aplicação de normas num Estado Democrático de Direito, não pode significar erigirmos o STF (e/ou os demais Tribunais Superiores) à condição de Censor da sociedade, de forma que a ele caiba definir o cânon oficial de interpretação normativa, buscando-se com isso gerar estabilidade ao se criarem barreiras de acesso aos Tribunais. Dessa forma, entendemos que segurança jurídica apenas pode significar hoje a garantia de que a proteção contra qualquer (alegação de) "lesão ou ameaça a direito" encontre no Judiciário a resposta adequada, ou seja, onde as partes possam ter a certeza de que a decisão foi formada a partir daquilo que elas produziram em contraditório no processo, ao mesmo tempo em que resulta da reconstrução do Ordenamento." (BAHIA, Alexandre Gustavo Melo Franco. Recursos Extraordinários no STF e no STJ: conflito entre interesses público e privado. Curitiba: Juruá Editora, 2009, p. 220/221.)

31 "Isso talvez possa parecer um pouco estranho, dado nosso apego ao texto, não causa espécie aos juízes do common law. Já que tantos dos que defendem a Súmula Vinculante se espelham na Suprema Corte dos Estados Unidos, vale a pena lembrar que os juízes americanos, em boa parte dos casos que têm a julgar, se esforçam para se desvencilhar da força do stare decisis." (Ibidem, p. 221.)

${ }^{32}$ BAHIA, Alexandre Gustavo Melo Franco. Recursos Extraordinários no STF e no STJ: conflito entre interesses público e privado. Curitiba: Juruá Editora, 2009, p. 221/223. 
É necessário, portanto, um Poder Judiciário que se preocupe em democratizar o processo, pois a atividade jurisdicional deve ser movida pelo discurso e pela participação efetiva dos interessados, ou seja, as decisões devem ser pautadas a partir das pretensões argüidas pelas partes em meio ao processo.

Consoante o entendimento de Aroldo Plínio Gonçalves ${ }^{33}$ :“o procedimento é uma atividade preparatória de um determinado ato estatal, atividade regulada por uma estrutura normativa, composta de uma seqüência de normas, de atos e de posições subjetivas, que se desenvolvem em uma dinâmica bastante específica, na preparação de um provimento."

Se, pois, no procedimento de formação do provimento, ou seja, se nas atividades preparatórias por meio das quais se realizam os pressupostos do provimento, são chamados a participar, em uma ou mais fases, os "interessados", em contraditório, colhemos a essência do "processo": que é, exatamente, um procedimento, ao qual, além do autor do ato final, participam, em contraditório entre si, os "interessados", isto é, os destinatários dos efeitos de tal ato. ${ }^{34}$

Nesse passo, requer-se a participação simetricamente igual dos interessados na construção do provimento, e, deste modo, nenhum julgador deve proferir qualquer decisão utilizando argumentos não debatidos pelas partes em contraditório, de maneira a haver um processo pautado em um procedimento democrático e discursivo.

Tal estrutura consiste na participação dos destinatários dos efeitos do ato final em sua fase preparatória; na simétrica paridade das suas posições; na mútua implicação das suas atividades (destinadas, respectivamente, a promover e impedir a emanação do provimento); na relevância das mesmas para o autor do provimento; de modo que cada contraditor possa exercitar um conjunto - conspícuo ou modesto, não importa - de escolhas, de reações, de controles, e deva sofrer os controles e as reações dos outros, e que o autor do ato deva prestar contas dos resultados. ${ }^{35}$

Em um processo encarado sob uma perspectiva democrática há a construção do provimento Jurisdicional pelas partes em simétrica paridade de armas, sendo, necessário, portanto, o afastamento do decisionismo do julgador e a implantação da comparticipação na formação das decisões.

${ }^{33}$ GONÇALVES, Aroldo Plínio. Técnica Processual e Teoria do Processo. Rio de Janeiro: AIDE Editora, 2001, p. 102.

${ }^{34}$ FAZZALARI, Elio. Instituições de Direito Processual. Campinas: Bookseller, 1.ed., 2006, p. 33.

${ }^{35}$ FAZZALARI, Elio. Instituições de Direito Processual. Campinas: Bookseller, 1.ed., 2006, p. $119 / 120$. 
Seguindo Aroldo Plínio Gonçalves ${ }^{36}$, “o controle das partes sobre os atos do juiz é de suma importância e, nesse aspecto, a publicidade e a comunicação, a cientificação do ato processual às partes (que é, também, garantia processual) é de extrema relevância."
A implementação dinâmica dos princípios fundamentais do processo mediante a estruturação técnica adequada permitirá uma democratização do processo sem preocupações com o esvaziamento do papel diretor do juiz e do papel contributivo das partes na formação das decisões. ${ }^{37}$

O juiz deve ser visto como um garantidor dos direitos fundamentais, respeitando e assegurando às partes a participação na formação das decisões, ou seja, na produção do provimento Jurisdicional.

\begin{abstract}
Certo é que o Jurista não pode desenvolver o seu dever se ignora as outras componentes - morais, sociais, políticas, econômicas da comunidade; mas também os cultores destas últimas não podem operar nos setores de sua competência se não conhecem o papel que o direito tem na sociedade. É necessário, portanto, a consciência das rationes distinguendi da Jurisprudência e das outras "ciências sociais"; do fato de que cada uma delas tem formatado e utilizado - nem poderia ser de outra forma: não é lícito, também, o processo da história - instrumentos próprios para colher a realidade do próprio ponto de vista. Em suma, é contemplada a complementaridade das diversas abordagens; não é admitido, ao contrário, sincretismo de métodos. ${ }^{38}$
\end{abstract}

Nesse passo, o procedimento seria uma seqüência de atos valorados, que alcançariam o ato final proferido pelo magistrado, cuja formação todos concorreram, havendo uma combinação ${ }^{39}$, na qual haveriam conexões entre normas, atos e posições subjetivas em meio ao processo.

Por essa visão conclui-se que não existe entre os sujeitos processuais uma submissão das partes ao juiz e sim uma interdependência, sendo inaceitável, portanto, o esquema de relação jurídico processual.

Não se podem mais realizar interpretações do sistema processual
sem tomar por base o "modelo constitucional de processo" e sem
perceber que além de se buscar a eficiência (geração de
resultados úteis) há de se buscar uma aplicação que implemente

${ }^{36}$ GONÇALVES, Aroldo Plínio. Técnica Processual e Teoria do Processo. Rio de Janeiro: AIDE Editora, 2001, p. 112.

${ }^{37}$ NUNES, Dierle José Coelho. Processo Jurisdicional Democrático. Curitiba: Juruá Editora, 2008, p. 197.

${ }^{38}$ FAZZALARI, Elio Fazzalari. Instituições de Direito Processual. Campinas: Bookseller, $1^{\text {a ed., }}$ 2.006, p. 75.

${ }^{39}$ FAZZALARI, Elio Fazzalari. Instituições de Direito Processual. Campinas: Bookseller, $1^{\text {a } e d ., ~}$ 2.006, p. 91. 
a percepção dinâmica das normas constitucionais, lidas de modo a permitir participação e legitimidade em todas as decisões proferidas. Inaugura-se uma concepção garantística do processo em contraponto e superação com sua concepção publicística e socializadora. $^{40}$

Fazzalari $^{41}$, ao adaptar o procedimentalismo democrático discursivo de Habermas ao processo, entende que a participação é um elemento estrutural e legitimante das atividades processuais, daí sendo importante a participação técnica das partes na construção do provimento Jurisdicional.

\begin{abstract}
Se, pois, o procedimento é regulado de modo que dele participem também aqueles em cuja esfera pública o ato final é destinado a desenvolver efeitos - de modo que o autor dele (do ato final, ou seja, o juiz) deve dar a tais destinatários o conhecimento da sua atividade, e se tal participação é armada de modo que os contrapostos "interessados" (aqueles que aspiram a emanação do ato final - "interessados" em sentido estrito - e aqueles que queiram evitá-lo, ou seja, os "contra interessados") estejam sob plano de simétrica paridade, então o procedimento compreende o "contraditório", faz-se mais articulado e complexo, e do genus "procedimento" é possível extrair a species "processo".,"42
\end{abstract}

Porém, infelizmente essa não a realidade atualmente vista atualmente no ordenamento jurídico brasileiro, na qual há a concentração excessiva de todo o poder decisório nas mãos do Judiciário diante da postura solipsista do magistrado na tomada de decisões, tornando-as cada vez mais arbitrárias.

$\mathrm{O}$ ativismo judicial vem sendo debatido pela doutrina, especialmente após a criação das Súmulas Vinculantes pela Emenda Constitucional 45/04 que acrescentou à Constituição o artigo 103 - A, conforme analisado anteriormente, como forma de uniformizar a jurisprudência e padronizar decisões.

\begin{abstract}
Além desse aspecto, não se pode mais acreditar em um Estado Democrático de Direito no qual o judiciário deixe de julgar casos e passe a julgar somente teses, como a lógica da produtividade e da eficiência a qualquer custo parece impor, que permite aos juízes exerçam um papel "judicializante" (da política e das relações sociais), que pode gerar impactos políticos, econômicos e jurídico nefastos. ${ }^{43}$
\end{abstract}

${ }^{40}$ NUNES, Dierle José Coelho. Teoria do processo contemporâneo. Revista da Faculdade de Direito do Sul de Minas, Edição Especial, 2008, p. 14.

${ }^{41}$ NUNES, Dierle José Coelho. Processo Jurisdicional Democrático. Curitiba: Juruá Editora, 2008, p. 207.

${ }^{42}$ FAZZALARI, Elio Fazzalari. Instituições de Direito Processual. Campinas: Bookseller, $1^{\mathrm{a} e d .}$, 2.006, p. 94.

${ }^{43}$ NUNES, Dierle José Coelho. Teoria do processo contemporâneo. Revista da Faculdade de Direito do Sul de Minas, Edição Especial, 2008, p. 14. 
Porém, a partir do momento em que há a possibilidade de edição de súmulas vinculantes pelos tribunais superiores com a obrigatoriedade de aplicação a todos os tribunais inferiores questiona-se a existência dos princípios como a inexistência de hierarquia entre os tribunais, liberdade de convencimento e independência do juiz enquanto agente político.

O que resta do direito? Qual é o papel da doutrina? Os julgamentos se tornaram monocráticos...! Milhares de processos são "resolvidos" no atacado...! Não mais discutimos causas, pois passamos a discutir "teses" jurídicas..! Como que a repetir a lenda do "leito de Procusto", as causas são julgadas de acordo com conceitos previamente elaborados (súmulas, repercussão geral, etc). E as ações são julgadas por "pilhas". Por isso, a repergunta: as duas décadas de fortalecimento do protagonismo judicial redundaram em que?

O que ocorreu é que voltamos a um lugar de onde nunca saímos: o velho positivismo. Isso porque apostamos em uma "autônoma razão teórica" e quando ela não é "suficiente", delegamos tudo para a razão prática ...! E o que é a "razão prática"? Na verdade, nem precisamos buscar auxílio na hermenêutica para falar sobre ela. Basta ver o que diz Habermas, na abertura de seu Fakticitat und Geltung: substituo a razão prática (eivada de solipsismo) pela razão comunicativa...! Claro que não concordo com a solução dada por Habermas, por razões já explicitadas em Verdade e Consenso. Mas é inegável que ele tem razão quando ataca de forma contundente o solipsismo. ${ }^{44}$

O processo judicial que deveria ser encarado como um procedimento em contraditório, resguardando os princípios constitucionais, ou seja, um processo mais democrático, tem a sua solução congelada, diante da aplicação da súmula em casos idênticos, de maneira a restringir a atuação das partes e até mesmo dos tribunais inferiores.

Há no caso o predomínio da assimetria, ou seja, as partes estão submetidas ao Poder Judiciário, ao juiz, em uma relação processual baseada na hierarquia. Com a concepção procedimental do Estado de Direito em Habermas busca-se uma reconstrução processual mais democrática.

Portanto, propõe-se um modelo democrático de processo em que predomina o policentrismo, ou seja, uma participação legítima e simétrica de todos os sujeitos participantes do processo, sem qualquer grau de hierarquia

\section{CONSIDERAÇÕES FINAIS}

No presente estudo conclui-se que as súmulas vinculantes estão fora dos parâmetros do Estado Democrático de Direito, pois a finalidade da súmula vinculante não é apenas orientar os tribunais inferiores, mas sim o que se

${ }^{44}$ STRECK, Lênio Luiz. O que é isto - decido conforme a minha consciência?. Porto Alegre: Livraria do Advogado, 2010, p. 106. 
pretende é uma única interpretação correta para certa situação com a obrigatoriedade de sua aplicação.

Pode-se concluir com a afirmação do autor ${ }^{45}$ "o ponto é que não somos gerais e não vivemos situações abstratas, logo, tal quais as normas, também as Súmulas terão de ser interpretadas - veja, não dissemos que elas "deveriam ser" interpretadas, a questão não é normativa, mas descritiva: quer se queira, quer não, a Súmula, como qualquer texto, "será" interpretada quando de sua aplicação - o exame dos casos que lhe deram origem poderia ser um primeiro passo interessante nesse sentido."

Ademais, é impossível o Poder Judiciário tentar engessar a interpretação através do "fechamento interpretativo" ocasionado pela súmula vinculante, sendo, portanto, necessário a existência de um processo constitucional democrático, havendo uma releitura da teoria habermasiana, ancorados em um espaço público voltado para participação simetricamente igual entre os interessados na construção do provimento, tornando a Justiça mais próxima dos cidadãos.

Por fim, percebe-se a necessidade do afastamento do decisionismo do julgador na tomada de decisões para que sejam abertos espaços alternativos que proporcionem a discussão, a comparticipação das partes na produção do provimento Jurisdicional, dentro de uma fase discursiva em meio ao próprio processo.

Conforme analisado, as decisões judiciais devem ser pautadas sobre argumentos de direito e oriundas da participação simétrica dos envolvidos, e não sobre questões religiosas, políticas, científicas, etc. Sendo assim é necessária a complementação das decisões com outros sistemas ou institutos, porém não a substituição pelo julgador de argumentos jurídicos por argumentos científicos, tecnológicos, religiosos, fora do âmbito do direito.

Ademais, nenhum julgador deve proferir qualquer decisão utilizando argumentos não debatidos pelas partes em contraditório, diante da necessidade da participação simetricamente igual dos interessados na construção do provimento, de forma que os cidadãos interessados se sintam mais próximos da Justiça, afastando, portanto, a idéia de que o juiz é o único portador da cognição para a elaboração das decisões judiciais.

Um processo constitucional democrático permitirá que o cidadão seja autodestinatário dos provimentos, seja no âmbito legislativo, administrativo e judicial, tendo que vista que a decisão não será apenas a expressão da vontade de maneira solitária pelo decisor, mas sim construída e discutida pelas partes endoprocessualmente.

45 BAHIA, Alexandre Gustavo Melo Franco. Reforma do Judiciário: o que uma súmula vinculante pode vincular? Revista Forense Eletrônica - Suplemento, volume 378, mar/abr. 2005, seção de doutrina, p. 670. 


\section{REFERÊNCIAS BIBLIOGRÁFICAS}

ATALIBA, Geraldo. República e Constituição. $2^{\mathrm{a}}$ ed., $2^{\mathrm{a}}$ tiragem, atualizada por Rosolea Miranda Folgosi. São Paulo: Malheiros, 2004.

AZEVEDO. Álvaro Villaça. Assentos e Uniformização de Jurisprudência. Enciclopédia Saraiva de Direito. R. Limongi França (coord.). v.8. São Paulo: Saraiva, 1978.

BAHIA, Alexandre Gustavo Melo Franco. Recursos Extraordinários no STF e no STJ: conflito entre interesses público e privado. Curitiba: Juruá Editora, 2009.

. Reforma do Judiciário: o que uma súmula vinculante pode vincular? Revista Forense Eletrônica - Suplemento, volume 378, mar/abr. 2005, seção de doutrina, p. 665/671.

Súmulas estão sujeitas a diversas interpretações. Disponível em: http://www.conjur.com.br/2009-ago-24/sumula-mesmo-vinculante-sujeitadiversas-interpretacoes. Acesso em 29/08/2009.

BENETI, Sidnei Agostinho. O processo na Suprema Corte dos Estados Unidos. O Judiciário e a Constituição. São Paulo: Saraiva, 1994.

BINENBOLN, Gustavo. A nova jurisdição constitucional brasileira. Rio de Janeiro; Renovar, 2004.

BONAVIDES, Paulo. Do Estado Liberal do Estado Social, Rio de Janeiro, Forense, 1980.

CANOTILHO, José Joaquim Gomes. Direito Constitucional e Teoria da Constituição. Coimbra: Almedina, 2001.

CATTONI, Marcelo. Direito Processual Constitucional. Belo Horizonte: Mandamentos Editora, 2001.

CRUZ, Álvaro Ricardo de Souza. Breve Histórico do Supremo Tribunal Federal e do Controle de Constitucionalidade Brasileiro. In: CRUZ, Álvaro Ricardo de Souza; SAMPAIO, José Adércio Leite (Coord.)Crise e Desafios da Constituição: perspectivas críticas da teoria e das práticas constitucionais brasileiras. Belo Horizonte: Del Rey, 2003,

DAVID, René. Os grandes sistemas do Direito Contemporâneo. 3.ed.São Paulo: Martins Fontes, 1996.

FAZZALARI, Elio Fazzalari. Instituições de Direito Processual. Campinas: Bookseller, 1 ${ }^{\text {aed., }} 2006$.

FRANCO, Henrique de Mello. Não existe modulação para a Súmula do Supremo. Disponível em: <http://www.conjur.com.br/2010-fev-21/nao-existemodulacao-sumula-vinculante-supremo>. Acesso em 03 março 2010. GONÇALVES, Aroldo Plínio. Técnica Processual e Teoria do Processo. Rio de Janeiro: AIDE Editora, 2001.

HABERMAS, Jürgen. A inclusão do outro - estudos de teoria política. 3.ed. São Paulo: Edições Loyola, 2007.

. Direito e Democracia entre a facticidade e a validade. 2. ed. Vol I e II.

Rio de Janeiro: Tempo Brasileiro, 2003. 
. Mudança estrutural da esfera pública. Rio de Janeiro: Tempo

Brasileiro, 2003.

JÚNIOR, Humberto Theodoro Jr. A onda reformista do Direito Positivo e suas implicações com o princípio da segurança jurídica. Revista de Doutrina da $4^{\mathrm{a}}$ Região, Porto Alegre, n.14, set 2006. Disponível em:

www.revistadoutrina.trf4.gov.br. Acesso em: 01 jun. 2010.

LEAL, Victor Nunes. Passado e futuro da Súmula do STF. Revista da Ajuris, Porto Alegre, v. 25, p. 46-67, jul.1982.

LEITE, Rafael Franceschini. Informações quanto aos efeitos da Súmula Vinculante 8 frente aos créditos do INSS. Disponível em: < http://www.artigonal.com/direito-tributario-artigos/informacoes-quantoaosefeitos-da-sumula-vinculante-8-frente-aos-creditos-do-inss 759719.html>. Acesso em 03 março 2010.

MERRYMAN, John Henry; PERDOMO Rogelio Pérez. A Tradição da Civil Law. Porto Alegre: Sérgio Antônio Fabris Editor, 2009.

MIRANDA, Francisco Pontes de. Comentários ao Código de Processo Civil [1939]. 2 ed. Tomo XII. Rio de Janeiro: Forense, 1961.

NUNES, Dierle José Coelho. Processo Jurisdicional Democrático. Curitiba: Juruá Editora, 2008.

. Teoria do processo contemporâneo. Revista da Faculdade de Direito do Sul de Minas, Edição Especial, 2008, p. 13 - 29.

. OLIVEIRA, Marcelo Andrade Cattoni de. Súmula Vinculante 5 do

Supremo Tribunal Federal é inconstitucional. Disponível em: <

http://www.conjur.com.br/2008-mai-22/sumula_vinculante_stf_inconstitucional $>$ Acesso: 03 abril 2010.

OLIVEIRA, Marcelo Andrade Cattoni de. Direito, Política e Filosofia. Rio de Janeiro: Lúmen Juris. 2007.

. A Súmula vinculante n. 4. do STF e o "desvio" hermenêutico do TST:

notas programáticas sobre a chamada "nova configuração" da jurisdição constitucional brasileira nos vinte anos da Constituição da República. In Constituição e Processo: a Contribuição do Processo ao Constitucionalismo Democrático Brasileiro. Belo Horizonte: Del Rey, 2009.

PEREIRA, Rodolfo Viana. Direito Constitucional Democrático. Rio de Janeiro: Lúmen Júris, 2008.

Rey, 2007.

Hermenêutica Filosófica e Constitucional. 2. ed. Belo Horizonte: Del

ROCHA, José Jardim. Supremacia da Constituição ou Supremacia do "defensor" da Constituição? O stare decisis e o Efeito Vinculante nas decisões da Suprema Corte. Brasília, v.7, n. 73, junho/jullho 2005. Disponível em: http://www.planalto.gov.br/ccivil_03/revista/rev_73/artigos/josejardim_rev73.ht m .> Acesso em: 02. abril.2010.

REPOLÊS, Maria Fernanda Salcedo. O papel político do Supremo Tribunal Federal e a hermenêutica constitucional: considerações partir da teoria, da cultura institucional e da Jurisprudência. Revista do Curso de Direito da 
Faculdade Metodista Isabela Hendrix, Nova Lima, v. 1, p. $102-108,1^{\circ}$ semestre 2003.

SANTOS, Boaventura de Sousa. Para uma Revolução Democrática da Justiça. São Paulo: Cortez, 2007.

SARMENTO, Daniel. O Neoconstitucionalismo no Brasil: riscos e possibilidades. São Paulo: Revista dos Tribunais, 2009.

SILVA, Nuno J. Espinosa Gomes da. História do direito português. 2. ed. Lisboa: Fundação Calouste Gulbenkian. 2006

SCHAUER, Frederick. Precedent. Standford Law Review. Standford, CA, v. 39, p. 571-605, Feb, 1987.

SIMIONI, Rafael Lazzarotto. Direito e racionalidade comunicativa: a teoria discursiva do direito no pensamento de Jürgen Habermas. Curitiba: Juruá, 2007. STRECK, Lênio Luiz. Constituição, Sistemas Sociais e Hermenêutica; Desconstruindo os modelos de juiz: a hermenêutica jurídica e a superação do sujeito - objeto. Porto Alegre: Livraria do Advogado, 2008.

. Hermenêutica Filosófica e Constitucional. 7. ed. Porto Alegre:

Livraria do Advogado, 2007.

Jornal Carta Forense: entrevista Direito Sumular. Disponível em:

http://leniostreck.com.br/index.php?option=com_content\&task=view\&id=82\&I temid=2. Acesso em: 29 jan.2009.

O que é isto - decido conforme a minha consciência? Porto Alegre:

Livraria do Advogado, 2010.

. Verdade e Consenso. Constituição, Hermenêutica e Teorias

Discursivas da Possibilidade à necessidade de respostas corretas em Direito. 2.ed. Rio de Janeiro: Lúmen Juris , 2007.

. Verdade e Consenso. Constituição, Hermenêutica e Teorias

Discursivas da Possibilidade à necessidade de respostas corretas em Direito.

3.ed. Rio de Janeiro: Lúmen Juris , 2009.

TORRES, Ricardo Lobo. Normas de Interpretação e Integração do Direito

Tributário. 3. ed, Rio de Janeiro : Renovar, 2000.

Recebido em 12-02-2011

Avaliado em 29-10-2011

Aprovado para publicação em 05-12-2011 